\title{
Perbandingan Kadar Hemoglobin Pengguna Rokok Elektrik dan Rokok Konvensional pada Pria Dewasa di Manado
}

\author{
${ }^{1}$ Mark M. Waleleng \\ ${ }^{2}$ Linda W. A. Rotty \\ ${ }^{2}$ Efata Polii
}
${ }^{1}$ Program Studi Pendidikan Dokter Fakultas Kedokteran Universitas Sam Ratulangi Manado
${ }^{2}$ Bagian Ilmu Penyakit Dalam Fakultas Kedokteran Universitas Sam Ratulangi Manado Email: markiiwaleleng@gmail.com

\begin{abstract}
Smoking has become a daily habit in Indonesia. Manado has a percentage of smokers as many as $23.6 \%$. Many efforts have been done to find alternative tobacco cigarette. Electric cigarette is one of the new models to replace tobacco cigarette. This study was aimed to determine the ratio of hemoglobin levels in adult male electric cigarette users in Manado. This was an observational analytical study using a cross sectional design. Samples were obtained by using decisive sampling technique. There were 20 electric cigarette users and 20 conventional cigarette users in this study. The results showed that the mean hemoglobin level of conventional cigarette users was higher $(17.080 \mathrm{~g} / \mathrm{dl})$ than of electric cigarette users $(14.335 \mathrm{~g} / \mathrm{dl})$. The bivariate analysis using the $\mathrm{T}$ test $(\alpha=0.05)$ of the comparison of hemoglobin levels in electric cigarette users and conventional cigarette users resulted in a $P$ value of 0.000. Conclusion: There was a significant comparison of hemoglobin levels in users of electric cigarettes and of conventional cigarettes among adult males in Manado.
\end{abstract}

Keywords: electric cigarettes, conventional cigarettes, hemoglobin

\begin{abstract}
Abstrak: Merokok sudah menjadi kebiasaan sehari-hari bagi masyarakat Indonesia. Kota Manado memiliki persentase perokok sebanyak 23,6\%. Banyak upaya yang telah dilakukan untuk mencari alternatif rokok tembakau. Rokok jenis elektrik merupakan salah satu fenomena baru yang diupayakan untuk mengganti rokok tembakau. Penelitian ini bertujuan untuk mengetahui perbandingan kadar hemoglobin pada pengguna rokok elektrik pria dewasa di kota Manado. Jernis penelitian ialah analitik observasional dengan desain potong lintang. Teknik pengambilan sampel menggunakan decisive sampling dengan jumlah sampel sebanyak 20 orang pengguna rokok elektrik dan 20 orang pengguna rokok konvensional. Hasil penelitian menunjukkan perbandingan kadar hemoglobin pada pengguna rokok elektrik dan rokok konvensional dimana rerata kadar hemoglobin pengguna rokok konvensional lebih tinggi $(17,080 \mathrm{~g} / \mathrm{dl})$ dibandingkan pada pengguna rokok elektrik $(14,335 \mathrm{~g} / \mathrm{dl})$. Hasil uji analisis bivariat menggunakan uji $\mathrm{T}$ terhadap perbandingan kadar hemoglobin pengguna rokok elektrik dan rokok konvensional pada pria dewasa dengan derajat kepercayaan $\alpha=0,05$ mendapatkan $P=0,000$. Simpulan: Terdapat perbandingan bermakna dari kadar hemoglobin pengguna rokok elektrik dan rokok konvensional pada pria dewasa di Manado.
\end{abstract}

Kata kunci: rokok elektrik, rokok konvensional, hemoglobin

Merokok sudah menjadi kebiasaan seharihari bagi masyarakat Indonesia. Terlepas dari banyaknya jumlah pengguna rokok tembakau, Indonesia juga sebagai salah satu negara penghasil atau produksi rokok tembakau dengan data menurut Riset Kesehatan Dasar (Riskesdas) tahun 2013 memperlihatkan perokok di Indonesia sebesar 29,3\% dari 237.641.326 penduduk di Indonesia. Kota Manado memiliki 
persentase perokok sebanyak $23,6 \%{ }^{1}$ Bahaya yang terkandung pada rokok tembakau tidak membuat pengguna rokok jera dan berhenti mengonsumsi rokok tembakau. Banyak upaya yang telah dilakukan untuk mencari alternatif rokok tembakau. Rokok jenis elektrik merupakan salah satu fenomena baru yang diupayakan untuk mengganti rokok tembakau. ${ }^{2}$

Rokok elektrik merupakan alat yang mampu menghasilkan nikotin dalam bentuk uap yang menggunakan tenaga baterai, namun tidak membakar tembakau seperti rokok biasa. Menurut Kepala Badan Pengawasan Obat dan Makanan (BPOM) rokok elektrik bekerja dari proses penguapan cairan (liquid) oleh kawat listrik yang dipanaskan. ${ }^{2}$ Proses penguapan tersebut yang menghasilkan uap air dan memberikan sensasi seperti merokok. Hal tersebut dikarenakan tidak adanya asap yang keluar, melainkan uap air sehingga timbul stigma rokok elektrik 'lebih aman' daripada rokok tembakau. ${ }^{3}$

Penelitian yang dilakukan oleh Center for Tobbaco Control Research and Education University of California menyimpulkan bahwa penggunaan rokok elektrik tidak lebih baik dibanding rokok tembakau dan tidak cukup membantu seseorang mengatasi kecanduan merokok tembakau. ${ }^{4}$ BPOM menjelaskan bahwa sejumlah bahaya terkandung di dalam rokok elektrik, seperti kandungan nikotin cair dan bahan pelarut propilen, glikol, dieter glikol, dan gliserin. Jika bahan-bahan tersebut dipanaskan, maka akan menghasilkan senyawa nitrosamine yang dapat menyebabkan penyakit, salah satunya yaitu penyakit kanker. ${ }^{2}$

Seiring dengan rokok elektrik yang menjadi tidak lebih baik dari rokok tembakau dan semakin populernya rokok elektrik bagi gaya hidup masyarakat menengah atas, ancaman bahaya di balik rokok elektrik semakin mengkhawatirkan. Banyak dampak yang dapat terjadi pada kesehatan tubuh manusia terkait pada rokok elektrik dalam hal ini kadar hemoglobin.

Hemoglobin sendiri merupakan protein utama tubuh manusia yang berfungsi mengangkut oksigen dari paru-paru ke jaringan perifer dan mengangkut $\mathrm{CO} 2$ dari jaringan perifer ke paru-paru. ${ }^{5}$ Kadar hemoglobin ditentukan dari pola konsumsi makanan dan minuman sehari-hari termasuk pola hidup manusia. ${ }^{6}$

Banyak cara yang telah ditemukan untuk pemeriksaan hemoglobin. Metode yang dianjurkan oleh International Committee for Standardization in Hematology yaitu metode sianmethemoglobin (autoanalyzer), dengan menghitung secara otomatis kadar hemoglobin dalam eritrosit. Metode ini telah banyak digunakan dan mempunyai standar yang stabil. ${ }^{7}$

\section{METODE PENELITIAN}

Penelitian ini bertujuan untuk mengetahui perbandingan kadar hemoglobin pada pengguna rokok elektrik pria dewasa di kota Manado. Jenis penelitian ini ialah analitik observasional, dengan menggunakan desain potong lintang. Teknik pengambilan sampel menggunakan decisive sampling. Jumlah sampel yang diteliti sebanyak 20 orang pengguna rokok elektrik dan 20 orang pengguna rokok konvensional. Variabel penelitian yang diteliti ialah kadar hemoglobin pada pengguna rokok elektrik dan rokok konvensional pada pria dewasa di Manado.

\section{HASIL PENELITIAN}

Terdapat 20 orang pengguna rokok elektrik dan 20 orang pengguna rokok konvensional yang diikutsertakan sebagai subyek penelitian ini. Tabel 1 menunjukkan bahwa 15 dari 40 orang subyek berusia 1827 tahun. Dari 20 subyek pengguna rokok konvensional 12 orang diantaranya berusia 38-47 tahun.

Tabel 1. Penggolongan kelompok usia subyek penelitian

\begin{tabular}{cccc}
\hline $\begin{array}{c}\text { Kelompok } \\
\text { usia (tahun) }\end{array}$ & \multicolumn{2}{c}{ Perokok } & Total \\
\hline $18-27$ & 15 & 0 & 15 \\
$28-37$ & 4 & 8 & 12 \\
$38-47$ & 1 & 12 & 13 \\
Total & 20 & 20 & 40 \\
\hline
\end{tabular}


Tabel 2 menunjukkan perbandingan kadar hemoglobin pada pengguna rokok elektrik dan rokok konvensional pada pria dewasa di Manado. Didapatkan rerata kadar hemoglobin pengguna rokok konvensional lebih tinggi $(17,080 \mathrm{~g} / \mathrm{dl})$ dibandingkan pada pengguna rokok elektrik $(14,335 \mathrm{~g} / \mathrm{dl})$.

Tabel 3. Perbandingan kadar hemoglobin pada pengguna rokok elektrik dan rokok konvensional

\begin{tabular}{lcccc}
\hline \multicolumn{1}{c}{ Variabel } & n & $\begin{array}{c}\text { Mean } \\
(\mathbf{g} / \mathbf{d l})\end{array}$ & SD & $\begin{array}{c}\boldsymbol{P} \\
\text { value }\end{array}$ \\
\hline $\begin{array}{l}\text { Kadar Hb } \\
\text {-Rokok elektrik }\end{array}$ & 20 & 14,335 & 0,579 & 0,000 \\
$\begin{array}{l}\text {-Rokok } \\
\text { konvensional }\end{array}$ & 20 & 17,080 & 1,042 & \\
\hline
\end{tabular}

Berdasarkan hasil uji analisis bivariat menggunakan uji $\mathrm{T}$ melalui program pengolahan data SPSS dengan derajat kepercayaan $\alpha=0,05$ terhadap perbandingan kadar hemoglobin pengguna rokok elektrik dan rokok konvensional pada pria dewasa didapatkan $P=0,000$ artinya terdapat perbandingan bermakna kadar hemoglobin pengguna rokok elektrik dan rokok konvensional pada pria dewasa di Manado (Tabel 3).

\section{BAHASAN}

Hasil analisis perbandingan kadar hemoglobin antara pengguna rokok rokok elektrik dan rokok konvensional setelah dilakukan uji analisis mendapatkan hasil perbandingan yang bermakna pada kadar hemoglobin pengguna rokok elektrik dan konvensional (Tabel 2). Penelitian oleh Makawekes et $\mathrm{al}^{8}$ mendapatkan kadar hemoglobin darah pada pria pengguna rokok konvensional sebesar 16,263 (g/dl). Peningkatan kadar hemoglobin pada pria pengguna rokok konvensional disebabkan karena adanya karbonmonoksida pada rokok konvensional yang mengikat hemoglobin sehingga membentuk karboksi hemoglobin. Peristiwa tersebut mengakibatkan berkurangnya fungsi hemoglobin sehingga tubuh mengompensasi penurunan kadar oksigen dengan cara meningkatkan kadar hemoglobin. ${ }^{8}$

Hal ini sejalan dengan hasil penelitian ini yang mendapatkan bahwa terdapat perbandingan bermakna dari kadar hemoglobin pada pengguna rokok konvensional dengan rerata sebesar 17,080 g/dl dan pada pengguna rokok elektrik sebesar 14,335 $\mathrm{g} / \mathrm{dl}$.

\section{SIMPULAN}

Berdasarkan hasil penelitian ini dapat disimpulkan bahwa terdapat perbandingan bermakna kadar hemoglobin dimana kelompok pengguna rokok konvensional memiliki rerata kadar hemoglobin yang lebih tinggi dibandingkan pengguna rokok elektrik.

\section{DAFTAR PUSTAKA}

1. Wibowo DV, Pangemanan DHC. Hubungan merokok dengan kadar hemoglobin dan trombosit pada perokok dewasa. eBm. 2017;5(1):1-6.

2. Badan POM. Info POM. Badan Pengawas Obat dan Makanan Republik Indonesia. Jakarta. 2015;16(5).

3. Hajek P, Etter JF, Benowitz N, Eissenberg T, Mcrobbie H. Electronic cigarettes: Review of use, content, safety, effects on smokers and potential for harm and benefit. Addiction. 2014;109(11):180110.

4. Fernandez E. Risk of heart attacks is double for daily e-cigarette users [Internet]. 2018. Available from: https://www.ucsf. edu/ news/2018/08/411476/ris k-heartattacks-double-daily-e-cigarette-users

5. Pearce E. Anatomi dan Fisiologi Untuk Paramedis. Jakarta: Gramedia, 2016.

6. Edmunson A. Memahami anemia. 2013. Available from: http://www.webmd. com/a-to-zguides/understandinganemia-basics

7. McPherson RA, Pincus MR. Henry's Clinical Diagnosis and Management by Laboratory Methods (22nd ed). Philadelphia: Saunder Elsevier, 2011.

8. Makawekes M, Kalangi SJR, Pasiak T. Perbandingan kadar hemoglobin pada pria perokok dan bukan perokok. eBm. 2016;4(5). 